\title{
Chapter 5 \\ Representing legitimate languages and identities: Strategies in higher education
}

Kiara Ríos Ríos grew up in La Mata, a small town towards the southeast of the Isthmus. She attended public schools in the region and especially enjoyed learning English, which motivated her to enroll in the bachelor's program in Enseñanza de Idiomas (Language Teaching/ Learning) at the Faculty of Languages of the Autonomous Beníto Juárez University of Oaxaca (UABJO), first in the Tehuantepec branch campus and then in the main campus in Oaxaca City. In the following extract from an interview conducted when she was nearing the end of her undergraduate studies, she reflects on how her interaction with a supportive teacher and interested peers during her studies led her to reevaluate her own language repertoire, in particular to give more importance to her ability to speak Isthmus Zapotec. She is confident and charismatic while narrating her experiences:

Kiara Lo que pasa es que al principio, yo sí, yo, el zapoteco para mí era para como algo para mi casa, así. O para aqui para mi pueblo, y todo eso para mí era el zapoteco. No era, como así pensaba yo, que no era para enseñar. Incluso apenas en la carrera aprendí que es una lengua. Yo pensaba que era un dialecto. Entonces todo, no le daba yo misma, no le daba mucho valor a mi lengua. Entonces fue en la escuela que, más cuando conocí al maestro Mario [López Gopar], que empecé yo a darle valor a mi lengua, porque, para mi antes no era como muy de presumir, así como sentirme bien por saber una lengua, no era algo que presumir.

Entonces, pero el maestro, como que, si sabes una lengua, es como para él, 'wuauuu'. Entonces yo misma la fui creyendo también. [. . .] Pues entonces fue así, que más o menos ya, él, él decía, 'no sé'- en mi grupo, así, antes que enseñara zapoteco - 'no sé si ustedes saben pero Kiara sabe hablar zapoteco' . . . [. . . Y Y muchos no sabían que yo hablaba, muchos no sabian, solo sabían los- mis círculos de amigos y así nada más, pero muchos no sabían, y ‘Enserio hablas zapoteco?’, y era así como, 'Sí enserio'. Este de, y ya te pregunta ‘'Y cómo, cómo aprendiste?’ y así. Entonces, a ti te va dando menos pena hablar, decir o ya no te da pena decir que hablas zapoteco, al contrario te enorgullece decir que hablas zapoteco. Es cuando, alguien también te ayuda a que le des valor a tu lengua, o que te sientas bien por hablar una lengua indígena.

The thing is that in the beginning, I yes, I, Zapotec for me was for, like something for my house, like that. Or for here, for my town, and all that was Zapotec for me. It was not, I thought like that, that it was not for teaching. Even just recently in the [university] program I learned that it is a language. I thought that it was a dialecto. So all, I didn't give it, myself, I didn't give much value to my language. So it was in school that, especially when I met teacher Mario [López Gopar], that I started to give value

Ә Open Access. (c) 2021 Haley De Korne, published by De Gruyter. (c) BY-NC-ND This work is licensed under the Creative Commons Attribution-NonCommercial-NoDerivatives 4.0 International License.

https://doi.org/10.1515/9781501511561-005 
to my language. Because before for me it wasn't really something to brag about, like to feel good for knowing a language, it wasn't something to brag about.

So, but for the teacher, like if you know a language, it's like 'woooow' for him. So I started to believe it myself as well. [. . .] Well so it was like that, that more or less then, he said, 'I don't know'- in my [university cohort] group, like that, before I was going to teach Zapotec - 'I don't know if you all know, but Kiara knows how to speak Zapotec' . . . [. . . ] And many didn’t know that I spoke, many didn't knowonly my circles of friends knew and no more, but many didn't know, and 'Seriously, you speak Zapotec?', and it was like that like, 'Yes, seriously'. And um, and then they ask you 'And how, how did you learn?' and so forth. So it starts to make you less embarrassed to speak, to say, or now it doesn't embarrass you to say that you speak Zapotec, on the contrary it makes you proud to say that you speak Zapotec. That's when someone also helps you to value your language, or so that you feel good for speaking an Indigenous language.

(Interview December 2013)

Kiara's experience is echoed in the comments of many other university students at the UABJO Faculty of Languages who note that their time at the Faculty changed the way they view Indigenous languages and Indigenous language speakers - including both students who speak Indigenous languages and those who do not. In her account of going from embarrassment about her language repertoire when she entered university to identifying as an Isthmus Zapotec speaker and taking up an opportunity to teach Isthmus Zapotec to other students in the Faculty as part of her teaching practicum, Kiara highlights the crucial role of her teacher, Mario López Gopar, and the interest of her peers. Despite having come out of primary and secondary education in the Isthmus with the internalized belief that Zapotec was a dialecto and "not for teaching", her experiences in higher education were impactful enough to change this perspective. Although primary and secondary education is clearly a period where language attitudes and competences are formed, as discussed in chapter 4, for those who continue into higher education this is also a significant moment where exposure to new and potentially more diverse perspectives can occur. In this case, the perspectives that Mario López Gopar, a Oaxacan scholaractivist-educator working on decoloniality and language education (López Gopar, Morales, and Jiménez 2014; López Gopar et al. 2013; López Gopar 2016), brought into the classroom helped Kiara and other students to question the assumed language hierarchy that they had grown up with. In addition to allowing a wider range of critical perspectives, higher education is also a crucial gate-keeping space where future educational authorities are formed and legitimated, in particular future teachers who will have a say in the language practices and politics of classrooms in years to come. 
In this chapter, I analyze the inclusion of Indigenous languages, in particular Isthmus Zapotec, within the Tehuantepec branch of the UABJO Faculty of Languages. The UABJO is the largest public university in the state of Oaxaca, and the Faculty of Languages has its main campus in Oaxaca City, with much smaller branch campuses in Tehuantepec (the historical market hub and namesake of the Isthmus) and Puerto Escondido, to the north on the Pacific coast of Oaxaca. The Tehuantepec Faculty of Languages became one of the focal sites that I have spent extended time in, initially observing and eventually collaborating with administrators and teachers, and getting to know several generations of students (see section 1.6 on methodology). I begin with a discussion of the numerous factors influencing how young adults in the Isthmus view their communicative repertoires, illustrating how multilingualism and Zapotec competence are often viewed through a deficit lens (5.1). Against this backdrop, I analyze how administrators and teachers in the Faculty of Languages engaged in language activism to support their students and change the colonialist bias of Mexican higher education (5.2). Their strategies included providing a new legitimacy for Zapotec as an academic language, and legitimacy for younger speakers through positive representations of Indigenous languages and of multilingualism (5.2.1). Furthermore, efforts to prepare young Zapotec teachers and to create new teaching and learning spaces within the structure of the university have been challenging, but hold important long-term promise (5.2.2). In summary, by working to fill a key identity category in the chain of language politics - that of language teachers - the community of the Tehuantepec Faculty of Languages have achieved slow, but structurally-supported forms of language activism (5.3). I consider the imaginaries and strategies of some of the teachers and administrators who were involved in supporting the program and the experiences of young adult learners of Isthmus Zapotec. I highlight the significance of higher education in representing local Indigenous languages and multilingual youth (or communication practices and identities, within the strategies framework) as legitimate. In this way, the gate-keeping and legitimation power of higher education has an important role to play in shaping language ecologies and in some cases in fostering potential language activists. The power to create certified language teachers (a special kind of sociallyrecognized identity) places higher education institutions at an especially significant point in the language ecology. A lack of teachers with competence to teach Diidxazá, and a lack of preparation and support among those who were attempting to teach it, was a common complaint within the education institutions I visited at all levels, and is common in Indigenous language education around the world (Whitinui, Rodríguez de France, and McIvor 2018). An institution such as the Tehuantepec Faculty of Languages is uniquely positioned 
to help supply this lack, and additionally holds the power to define what the qualities and abilities of a recognized Diidxazá teacher should be.

\subsection{Multilingualism and identities in the Isthmus}

Our identities as speakers and communicators are formed through countless influences in our home and surrounding environments. Our communicative repertoires and what we think and believe about those repertoires are likely to change over time as we encounter new influences or make new choices in our lives (Gumperz 1964; Busch 2012), as Kiara's description of her changing perspective and confidence as a speaker of Zapotec quoted in the opening of this chapter illustrates. The communicative repertoires of Indigenous youth, and their attitudes towards different communication practices, are subject to many, often contradictory, influences. The dominance of Eurocentric ideologies which devalue Indigenous languages, as discussed in chapter 2 in particular, has a clear influence on how Istmeños view their communicative repertoires. Ríos Ríos's comment that she viewed Zapotec as a dialecto is a common one, as is the view that Spanish and English are inherently superior, leading people to hide their knowledge of Indigenous languages. For many people in the Isthmus and elsewhere in Mexico, the idea of studying languages means studying European languages. One student who had migrated to the Isthmus for work and participated in a weekend class at the UABJO commented:

Student 1 A mis papás les dije . . . les dije 'oye, que crees, mira aquí donde estoy hablan zapoteco, y estoy aprendiendo.' $Y$ se empezaron a reír así burlonamente, 'Oh! Oh! Oh! Zapoteco . . . Hola, aprende mejor el inglés’, y se empezaron a reír.

I told my parents . . . I told them 'hey, guess what, look here where I am they speak Zapotec, and I'm learning.' And they started to laugh like this mockingly 'Oh! Oh! Oh! Zapotec . . . Hello, learn English instead', and they started to laugh.

(Interview October 2013)

This student's parents are not alone in viewing English and other European languages as the only legitimate languages to study. With the long precedent of castellanización (Spanish-ization, see chapters 2 and 4) in primary and secondary schooling, higher education has generally served to extend this ideology, eventually carrying it over towards the work place and other prestigious spheres of public life.

In addition to a bias towards European languages, there is also a monolingual ideology which is prevalent in the region as discussed in chapter 2. Warnings that children will become enredado [tangled] if they learn both Spanish 
and Zapotec at the same time are common, as are critiques of what is perceived as mixing, and thus denigrating, languages. Mixed or synthetic communication (incorporating communicative resources perceived as Spanish and resources perceived as Isthmus Zapotec; see Hill and Hill 1986 in the context of Nahuatl and Spanish) is the norm in the Isthmus, yet many people also point to this practice as something negative, a degradation of Zapotec or poor Spanish. This is common in other Indigenous and minoritized communities, resulting in discouraging youth from viewing themselves as speakers (Meek 2010) and devaluing the heteroglossic resources that youth employ, while upholding an idealized, monolingual-like norm (García 2009b). For example, Sheilah Nicholas (2019) discusses how a changing language ecology in the United States impacts the communicative repertoires of Indigenous Hopi youth and results in uncertainties about Hopi identity due to the close link between language and culture. In the Hopi case, she illustrates that identity is bound up in more than language competence, and that competence is not a binary characteristic. Likewise in the Isthmus, young adults' communicative repertoires are often different than those of their parents and grandparents, and some struggle to define for themselves which language(s) they consider to be theirs.

When talking with young adults who had grown up in the region, insecurity with their own communicative abilities was a common theme; many would comment that they speak some Zapotec, but not well, or that they understand but do not speak. Many related how one or more family members (often their father) were particularly opposed to their use of Zapotec. Being mocked or critiqued was also a common experience among young adults. As one university student recounted:

Student 2 Mi papa era el que siempre me decía que lo hablaba mal o esa no era la pronunciación y en vez de motivarme, no pues yo me sentía muy mal y mejor ya no loya no lo hablaba, dejaba pasarlo y ya. Pero mi mamá sí era la que me decía: 'No, pues háblalo. Es bonito aprender el zapoteco. Le vas a enseñar a tus hijos y pues, para que siga.'

My father was the one that always told me that I spoke it badly or that was not the pronunciation, and instead of motivating me, no, well I felt really bad, and better not to- then I didn't speak it, I let it go, that's all. But my mom, yes, was the one that would say to me: 'No, speak it. It's very good to learn Zapotec. You will teach it to your children and, well, so that it continues.'

(Interview July 2014)

While this student's father may not have been aiming to stop her use of Diidxazá, regular critique undermined her confidence and led her to "let it go". Despite the encouragement of some family members, such as this students' mother, she had 
experienced long-term discomfort and insecurity as a young speaker of Diidxazá. Situations like this position young speakers at a crossroads of multiple language ideologies or stigmas within and beyond the speech community; they may be critiqued by family members for not speaking the Indigenous language in a certain way and/ or they may be critiqued by family or community members for not speaking the Indigenous language at all. At the same time they may face prejudice in society for speaking an Indigenous language to any degree (Gal 2006). Navigating the various norms and ideologies that surround them is daunting.

A case in point is a university student from Juchitán who explained that although he learned Zapotec from his grandparents, with his parents and younger sister he uses almost all Spanish, partially for fear of making mistakes, partially due to his mother's desire to learn Spanish and avoid discrimination.

Student 3 De hecho, hasta ahorita se siguen dirigiendo en español. Muy pocas veces hablamos en zapoteco, o cuando entablamos una conversación mi mamá me habla en zapoteco y yo le contesto en español. Entonces tal vez no le hablo en zapoteco porque me da pena equivocarme, que no diga bien una palabra.

HDK ¿Estás más cómodo en español?

Student 3 En español, sí. Sí, ella a veces prefiere que le hable en español porque--- como mi mamá vende en el mercado, entonces ahí su vida cotidiana es zapoteco, zapoteco. Jamás habla español, más que cuando está en la casa con nosotros. Entonces cuando ella necesita ir al banco o a otro lado es en español y piensa que su español es malo, pero no. Entonces por eso prefiere hablar español con nosotros, porque así aprende el español. Pero por nuestra parte pues nos perjudica porque no practicamos zapoteco.

Student 3 Actually up until now they [my parents] keep addressing [me] in Spanish. We very rarely speak in Zapotec, or when we start a conversation my mom speaks to me in Zapotec and I answer in Spanish. So maybe I don't speak to her in Zapotec because I'm worried to make a mistake, that I won't say a word well.

HDK You're more comfortable in Spanish?

Student 3 In Spanish, yes. Yes, she [my mother] sometimes prefers that I speak to her in Spanish because- since my mom sells in the market, so there her daily life is Zapotec, Zapotec. She never speaks Spanish, except when she's in the house with us. So when she needs to go to the bank or another place it's in Spanish and she thinks that her Spanish is bad, but no [it's not]. So for that she prefers to speak Spanish with us, because she learns Spanish that way. But for us, well it harms us because we don’t practice Zapotec.

(Interview November 2014) 
Both the student and his mother experience insecurity with language, whether in relation to Zapotec or to Spanish. While he is worried about making a mistake when using Zapotec, his mother fears how she may be judged when speaking Spanish in the bank or other public spaces. Although he comments that she is wrong to believe her Spanish is bad, that it is not in fact bad, he does not extend the same recognition to himself and his abilities in Zapotec. A 'parallel monolingual' ideology, whereby multilinguals are expected to speak each language in a monolingual mode with no mixing (Heller 1999), is widespread in the Isthmus, among both older and younger generations.

The uncertainty that young speakers navigate is represented in a meme circulated in October 2013 by a popular public Facebook page dedicated to cultural issues in the Isthmus (Figure 13). In this meme, a recycled image of Kermit the frog gazing off into the distance is labelled with a text in Spanish and Isthmus Zapotec, which reads in English as "Sometimes I would like to show off/ put on screen that I know how to speak Zapotec. But then I remember that I only know how to say 'eat shit' [in Zapotec] . . . And I let it go." This quip recycles a frame from other memes of varying topics: "Aveces quisiera $X$, pero luego $Y$ y se me pasa.” [Sometimes I would like X, but then Y and I let it go/ I get over it].

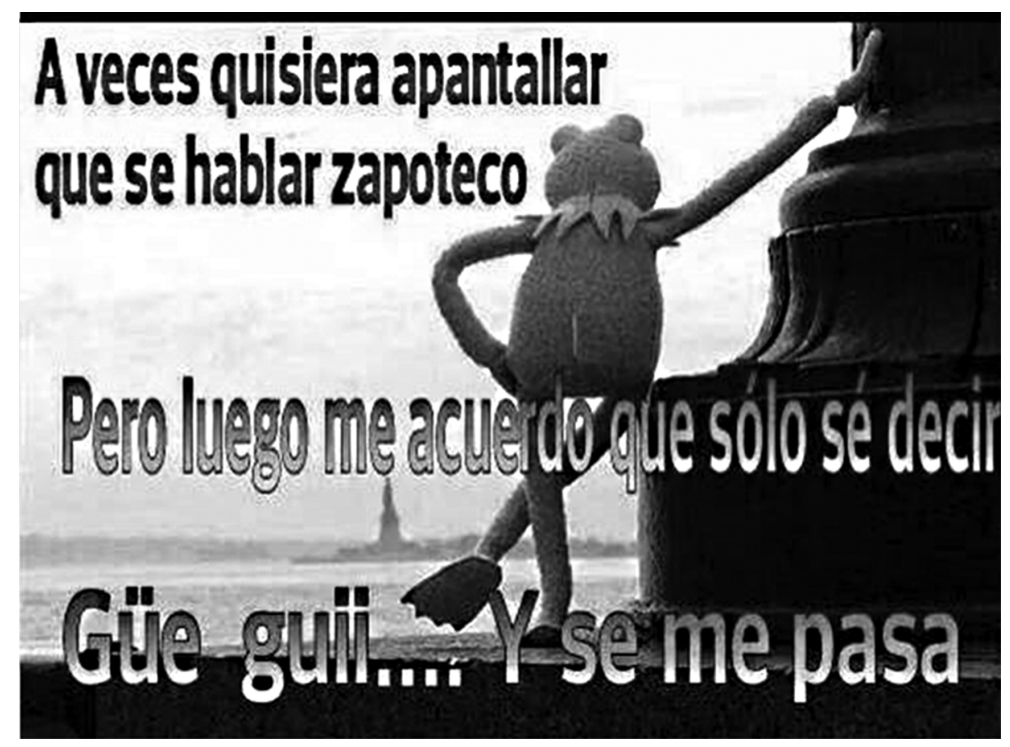

Figure 13: ‘Aveces quisiera apantallar que se hablar zapoteco. . .' meme. 
This meme elicited many shares and laughing comments, including comments of other words that might make up a basic Zapotec vocabulary, including 'guchachi' [iguana] or 'guetabingue' [a local kind of shrimp and corn dough dumpling]. While the creator of this meme took a humorous approach to the topic, the discourse that a person's communicative repertoire is not adequate to claim that they are a speaker of Zapotec is clearly recognized by many viewers. This is a common challenge in minoritized language communities. Young speakers' insecurity or perceived illegitimacy has been noted and discussed from the artic regions of North America, Europe, and Russia (Johansen 2010; Meek 2010; Wyman 2012; Ferguson 2019), to southern France and the Basque country (Urla 2012; Costa 2015), and many other places in between. Muehlmann (2008) has described a similar dynamic in a Cucapá community in northern Mexico, where younger generations are faced with an essentialized notion of what it means to be an Indigenous language speaker, a category from which they are largely excluded. In the Isthmus, being a 'Zapotec speaker' is not quite as restricted as the situation described by Muehlmann where only a small minority of the community are recognized to speak the Indigenous language, however it is still far from straightforward, and is influenced by the presence of multiple regional dialects as well as intergenerational change.

In a higher education context, monolingual ideologies are typically compounded by the standard language ideology which has characterized Spanish and other European languages in education. Standard ideologies of language promote a supposedly neutral, universal form of language as the norm- even when no such norm is possible (Milroy and Milroy 1999; Gal 2006). Most minoritized languages have not gone through the nation-state sponsored process of standardization, yet standard language ideologies are often pervasive in minority language education and reclamation movements (Costa, De Korne, and Lane 2017). Quechua scholar-activist Serafín Coronel-Molina (2015) critiques how efforts to produce standards and coin new words for Quechua are a central focus of the High Academy of the Quechua Language in Peru, yet are pursued largely in isolation from speakers and everyday language use. He points out that a standardization effort that is disconnected from everyday speakers tends not to be successful "since not only does it not have the support of the speech community, but often the community is not even aware of it” (2015: 212). This can create a double-bind for members of minoritized speech communities, who may be criticized for lacking authority and accuracy in an idealized pure or standard variety, while on the other hand they may be criticized for lacking authenticity if they adhere to a top-down norm or a degree of purism that is not in everyday use in the community (Gal and Woolard 2001; Woolard 2008). Education initiatives, while aiming to promote the use of minoritized languages, may 
delegitimize or leave out certain communication practices and speakers when shaped by purist, monolingual, or standard language ideologies (Heller and Martin-Jones 2001; Urla et al. 2017).

At the same time, education initiatives can have significant positive impacts on the trajectories and well-being of Indigenous or minority youth, as examined in chapter 4. Scholars have discussed the importance of approaching minority language education through additive bi/multilingualism and multiliteracies (Lambert 1975; Martin-Jones and Jones 2001). When endangered language communities have the authority to define what successful learning and revitalization is for themselves (Leonard 2012, 2017; Davis 2019) and to develop a community of practice which is inclusive of learners (Hermes and Engman 2017; Weinberg and De Korne 2016), endangered language education has been shown to have many positive results.

Students, teachers, and administrators engaging in the teaching and learning of Zapotec in higher education must navigate both the expectations and norms of the local speech community in the Isthmus and those of additional language learning as an academic discipline, neither of which have traditionally been very comfortable with multilingualism. In the following section I examine how the administrators and teachers of the Tehuantepec Faculty of Languages made strategic choices which went against the grain of devaluing Indigenous languages and valuing standard, monolingual communication. Their practices as education authorities and language policy arbiters created a space where multilingual youth could gain a new, more positive perspective on their communicative repertoires and in some cases identify as speakers of Isthmus Zapotec when they previously preferred to erase this part of their repertoire.

\subsection{Language activism in the Tehuantepec Faculty of Languages}

European languages, and particularly English, have traditionally been the focus of the educational offerings of the UABJO Faculty of Languages, both in the central campus in Oaxaca City, and in the branch campus in Tehuantepec. The Bachelor program offered in Tehuantepec since the branch campus was founded in 2000 was originally called Idiomas extranjeras con especialización en inglés [Foreign languages with a specialization in English], and was renamed Enseñanza de Idiomas [Language Teaching/ Learning] in 2012 as part of a wider shift in management within the Faculty. Even within the new BA program, English was a required subject for all 4 years of the program, although more space was created for a required additional 'optional' language (depending on availability, usually 
French or Italian). In the public courses offered at various levels, including courses directed at children and at adults, English was also the most common course offered, again with French and Italian as possible options if enrollment was high enough. In the words of Ximena Léon Fernández, the coordinator of public courses in 2013-2016 and a former graduate of the Faculty's BA program, for most of the Faculty's existence, “inglés era el rey" [English was king] (Interview July 2014). In this way, the language hierarchy in the Faculty reflected the coloniality of the language hierarchy in the region, and in Mexico more generally.

Although influenced by trends in the central campus in Oaxaca City, the Tehuantepec campus exists in a very different language ecology and socio-economic context. Not many of the students in the Tehuantepec campus were fortunate enough to take classes with Mario López Gopar, the professor Kiara describes in the opening citation, who is a prolific scholar and advocate of Indigenous rights and inclusive education, and teaches primarily in the Oaxaca City campus. While the Oaxaca City campus is home to the Cuerpo académico en Lingüística Aplicada Crítica [Research group on critical applied linguistics] lead by López Gopar, and benefits from the resources of the state's capital city, the Tehuantepec campus is a 5.5-hour bus ride away from the city. The focus in Tehuantepec has always been on providing basic language and teaching courses in a region with few higher education offerings, with most of the teachers at the Faculty holding Bachelor degrees in English or Education, and often being graduates of the Faculty itself. The Tehuantepec Faculty of Languages offers the BA program in both a full-time and a weekend-based part-time program, as well as individual language courses for the general public on evenings and weekends. There are numerous other higher education institutions in the Isthmus, none of which specialize in languages. There are no programs dedicated to the study of Isthmus Zapotec, although several institutions have engaged in various projects related to Diidxazá from perspectives of tourism, education, and technology development. Within this context, it was significant when the Tehuantepec Faculty of Languages initiated two Diidxazá classes as public weekend classes in February of 2013.

These classes were established through the initiative of Ximena Léon Fernández who became the coordinator of the public courses in late 2012. In the winter semester of 2013 she organized an offering of Diidxazá public courses on Saturdays, opening one group for 'beginners' and one for 'speakers'. The first class in spring 2013 was taught by the director of the cultural center in Juchitán, Vidal Ramirez Pineda. In that first semester many of the students from the BA enrolled, as well as some members of the public. Ximena also ran classes in Ombeayiüts (or Huave, an Indigenous language from the coast of the Isthmus), in 2014 but low enrollment levels meant that the class did not continue. Ximena collaborated 
with the coordinator of the BA program, Omelino Santos Medina, in order to establish Diidxazá as a possible 'optional' language in the BA program, so that students could have it as one of the languages that they would be certified to teach when they completed the program. In autumn of 2015, the Isthmus Zapotec class offerings expanded to encourage more students in the Bachelor's program to study Diidxazá. Several teachers have taught the classes, including Carlos Celaya Gómez, Didiert Hernández Martinez, Anaxhiely Osorio Sanchez, Leticia Gutierrez Pacheco, Margarito Vicente Santiago, Sergio Acevedo, and other students doing their teaching practicum (as discussed further in section 5.2.2). Zapotec has also been included in the summer programs offered for children and adolescents since 2014, often taught by teaching practicum students enrolled in the BA.

In 2017 the Faculty supported a proposal from an adjunt lecturer, Bania García Sanchez, to host a 'Café Literario' (Literary Café) focusing on the literature from the Isthmus, using bilingual versions in Spanish and Zapotec, with discussion mainly in Spanish. This was offered first as an extra-credit activity for BA students, and then due to its popularity it became a public course that BA students could enroll in. Bania began collaborating with Faculty employee Mónica Esteva García, who brought in a focus on 'rescate de zapoteco', [reclamation of Zapotec] into the course as well. Isthmus Zapotec has thus come to be present in the Faculty course offerings in various ways in recent years through initiatives such as these.

Throughout the process of establishing Isthmus Zapotec as part of the curricular offerings at the Faculty, numerous challenges have arisen, which the administrators and teachers have attempted to address. The well-established prejudice against Indigenous languages and the standard language ideologies in society and in Mexican higher education at large remain a reoccurring challenge, and enrollment levels in Indigenous language courses have at times been low. Additionally, the investment in educating Indigenous language teachers- while in many ways simultaneously defining the characteristics of the identity category of 'Isthmus Zapotec teacher'- has been a long-term and complicated undertaking. In the following sections, I highlight several of their most salient strategies, including representing Indigenous languages and speakers positively, creating space for Zapotec within the high-status space of the university, and creating Indigenous language teachers. Many people have participated in initiatives in various ways, and it is unfortunately not possible to provide an exhaustive description of all people and events that have helped to increase the status and presence of Isthmus Zapotec at the Tehuantepec Faculty of Languages. In the following sections, I highlight and analyze some of the initiatives and people working within the Faculty that 
I observed and came to know between 2013 and 2018 in order to illustrate the key changes underway.

\subsubsection{Representing legitimate languages and multilingual identities}

Due to its location in the center of Tehuantepec, a town at the crossroads of multiple Indigenous language communities, the Faculty of Languages has always had students who are speakers of Indigenous languages, especially Zapotec. Ximena Léon Fernández recounted that when she began as a student in the Bachelor's program in 2010 the presence of Zapotec speakers was common, but it was not considered "relevant" for the activities of the Faculty.

Ximena Nunca fue algo relevante en la facultad, ¿no? Ya que la licenciatura era una licenciatura en lengua extranjera con especialidad en inglés, nunca fue relevante que tuviéramos, como siempre he habido, alumnos que hablaran zapoteco.

It was never something relevant in the Faculty, right? Since the Bachelor's was a Bachelor's in foreign languages with specialization in English, it was never relevant that we had, as there has always been, students who speak Zapotec.

(Interview July 2014)

A unitary focus on the target language of English was pursued without interest for the languages that students already had in their repertoires. The notion that the students' existing abilities could serve as resources for them in learning English or any other language was not prevalent at that time.

Ximena is an exuberant, energetic teacher and coordinator, known for her colorful outfits, love of theater and the arts, and ambitious pursuit of growth and quality in the Faculty. She worked as an English teacher in central Mexico for many years before moving to the Isthmus to live with her extended family and pursue her Bachelor's degree. Although she grew up primarily in Mexico City, her family's origin in the Isthmus is meaningful to her, and she is proud to have roots there. She had heard her grandmother using some Zapotec words interspersed in their Spanish conversations throughout her life, and knew that her great-grandparents spoke Zapotec as their primary language. She had always been curious about this heritage, and became increasingly interested when she moved to the Isthmus as an adult and began studying in the Bachelor's program. Remembering that time, she said:

Ximena Siendo estudiante solamente de la facultad, era un interrogante, vamos, que había tenido, una pregunta que me había hecho; que ¿por qué no había cursos de zapoteco en la Facultad de Idiomas de Tehuantepec? Pues una vez que estuve en la posición de hacerlo, dije lo primero que tengo que hacer es eso. 
As just a student in the Faculty, it was a question, well, that I had had, a question that I had asked myself; why weren't there Zapotec classes in the Faculty of Languages of Tehuantepec? Well, once I was in the position to do it, I said the first thing that I have to do is that.

(Interview July 2014)

Ximena described the inclusion of Zapotec in the Faculty as more of an instinct than a rational plan; she had a feeling that this should be part of what a higher education institution in the Isthmus would provide. She articulated this stongly, stating that: "La facultad tiene la responsabilidad de preservar la lengua aquí, ¿no? De preservarlo de la forma que debe ser, lo que es teniendo cursos, de manera constante, de manera permanente" [The Faculty has the responsibility to preserve the language here, right? To preserve it in the way that it should, which is holding classes, in an constant way, in a permanent way] (Interview July 2014). This conviction that Indigenous languages should be included (and preserved) within the enduring structure of the institution continued to motivate her as she introduced, and later struggled to support, this fledgling initiative. She began with the area of the Faculty under her control, the weekend and evening courses open to the public, and began offering 2 sections of Diidxazá on Saturdays in 2013. These classes were open to both students in the Bachelor program and members of the public. She expanded courses to include an Ombeayiüts (Huave) class when she found that there were students in the Bachelor's program who were speakers of Ombeayiüts and interested in teaching it.

The Diidxazá classes attracted the interest of a sizable group of over a dozen students the first semester they were offered. Some of the participating students had Diidxazá competence and were interested in learning how to write and other formal aspects of the language, while others were new to the language and interested in learning the basics. One of the students from Tehuantepec, whose grandparents had spoken Zapotec but who had not grown up with much exposure to the language, told me that he thought learning a 'mother tongue' would be useful in applying for scholarships. Other students were interested in being able to communicate in Zapotec in the local environment, such as the market, or with their grandparents. One of the members of the public who enrolled in the course was a middle-aged man who worked in a school and described his motivation as rooted in his family heritage:

Student 4 Aunque he vivido aquí en la región, yo nací en la región, mi mamá hablaba zapoteco, mis abuelos hablaban zapoteco, pero yo no aprendí el zapoteco. Lo escuché. Porque en el lugar donde yo vivía, no se hablaba el zapoteco [...] Siempre había tenido la inquietud de estudiarlo no, en conocerlo. Pienso que por el hecho de venir de familia que habla el zapoteco se me puede facilitar a mí, y entonces fue que me decidí a estudiar el zapoteco. 
Although I have lived here in the region, I was born here in the region, my mother spoke Zapotec, my grandparents spoke Zapotec, but I didn’t learn Zapotec. I heard it. Because in the place where I lived Zapotec wasn't spoken. [. . .] I always had the impulse/ desire to study it, right, to know it. I think that due to coming from a family that speaks Zapotec it can make it easier for me, and so I decided to study Zapotec.

(Interview October 2013)

This student found it convenient to come to Saturday classes, and to build on the knowledge he already had of Zapotec. Although he had "always had the impulse to study it", this was the first time he was participating in a Zapotec class because he had never found an opportunity before.

While students generally appreciated the classes, there were also frustrations, in particular in relation to the lack of a set curriculum, the different levels mixed together in class, and the issue of dialect diversity. The varying levels of background knowledge and varying expectations of the participating students presented the teachers with a steep challenge. As discussed in chapter 2, there are 4 regionally-recognized varieties of Isthmus Zapotec. Tehuantepec itself is one of the areas of the region where language shift towards Spanish is most advanced, and speakers of Zapotec from Tehuantepec are typically in their 70s or above. However, the adjacent village of San Blas Atempa is characterized by active Zapotec use. For some students, the appropriate dialect to teach in Tehuantepec would be the dialect of San Blas, which is close to that of Tehuantepec. Many Isthmus Zapotec activists and writers have been speakers of the Juchitán dialect, the variety which has the most speakers due to its use in the city of Juchitán and several surrounding villages. This is also the variety that aligns most closely with the alfabeto popular, the writing system that is the generally-accepted standard for Isthmus Zapotec (see section 2.5 and chapter 6). The first teacher employed by the Faculty of Languages was from Juchitán; although he made efforts to include dialect diversity into his teaching, this was also an area of dissatisfaction among some students. A student from San Blas commented that she appreciated the efforts to include other varieties, but it was still a source of frustration for her:

Student 5 Lo que nos enseña más que nada es el zapoteco, la variante de Juchitán. Sí nos dice, no, de repente, 'esta palabra se dice así en Juchitán pero en tal lugar se dice así y en otro tal lugar se dice así' y. . . Quizá es como también una necesidad mía el aprender la variante de mi pueblo y... Quizá mí mismo cuerpo se resiste un poquito, no. 
What he teaches us mainly is Zapotec, the variety from Juchitán. Yes he tells us, right, suddenly/unpredictably, 'this word is said this way in Juchitán but in such a place it is said this way and in another place it is said this way' and . . . Maybe it is like also a need I have to learn the variety of my village and . . . Maybe even my body is resisting a little bit, right.

(Interview October 2013)

When many students are learning for personal heritage motivations, or to be able to speak with elderly members of their community, the question of which variety is being taught takes on a heightened importance. Although most of the teachers I have observed in the Isthmus attempt to give value to all varieties, this is difficult to put into practice in the classroom.

At the same time, students arrive in class with expectations formed by standard language ideologies, and some would like the teacher to choose one variety to teach. The view that there is one right way to speak or write each word in a language is common in the Spanish and English classes that they have taken, and comes to influence their expectations for learning Zapotec. While some students commented in interviews that they believe the variety of San Blas/ Tehuantepec should be taught for geographical reasons, others commented that they wanted to learn the variety of Juchitán because it has the highest profile in the media, publishing, and is used in more places. This compounded the alreadydifficult challenge of teaching students with a wide range in prior knowledge. The study whose "body was resisting" learning the Juchitán variety had a high level of comprehension, and could be described as a fluent listener. However, when it came to a written vocabulary test that the teacher gave towards the end of the semester, the student had one of the lower scores in the class and dropped out of the class the following semester. The multi-variety, multi-level nature of the Isthmus Zapotec speech community - and of the students arriving in the class - presented a challenge which teachers at the UABJO continue to work with. The non-standard nature of Diidxazá, and lack of a fixed curriculum, made it harder for this language to be included in the institutional structure of the Faculty in the same way that English, French and Italian were included.

Despite these challenges, the presence of the Diidxazá classes had an effect on students and teachers in the Faculty. As Ximena observed "El simple hecho de saber en la Facultad había un grupo de zapoteco, empezó a generar un cambio en la gente no, un cambio de actitud ante la lengua" [The simple fact of knowing that there was a class group in Zapotec in the Faculty started to generate a change in people, a change in attitude towards the language] (Interview July 2014). She argued that this change was significant, even if only a minority of students were choosing to enroll in the classes. Posters advertising courses listed Zapotec (and 
for a time, Huave) alongside French and English, and Ximena endeavored to promote Zapotec courses prominently in the hopes of increasing enrollment. Figure 14 shows her conducting publicity for the Faculty of Languages by handing out flyers and coupons for 100 pesos off enrollment in Zapotec classes in a public park in the center of Juchitán. The banner advertises the "Autonomous Beníto Juárez University of Oaxaca; Faculty of Languages; Campus Tehuantepec; Bachelor's degree in Language Teaching/ Learning; Semester courses; Summer courses; Intensive courses; Zapotec; English; French; Italian; Spanish”. Listing Zapotec first in publicity was a strategic choice that Ximena hoped would help to make the classes visible and raise the status of the language, even though in practice there was a much larger demand for English classes.

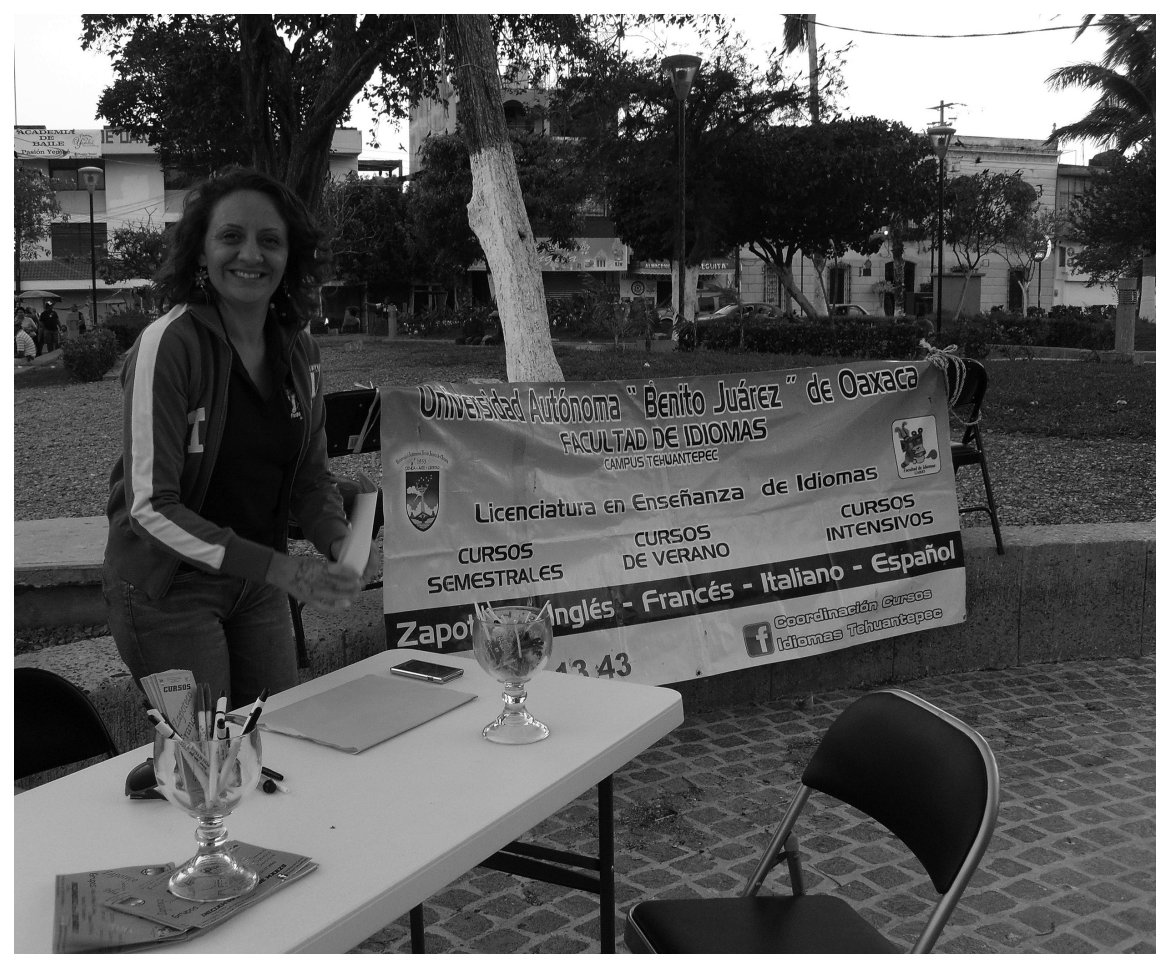

Figure 14: Ximena Léon Fernández distributing flyers in a public park in Juchitán to promote UABJO courses (photo February 2014).

The Literary Café initiated and run by Bania García Sanchez and Mónica Esteva García, and supported by the coordinators, was another reflection of the wider acceptance and interest in Indigenous languages within the Faculty. Bania and 
Mónica are both from parts of the Isthmus where Spanish is dominant, and both grew up using primarily Spanish in families with Zapotec heritage. They completed Bachelor's degrees outside of the Isthmus, and Bania additionally completed a Master's degree where she researched Isthmus Zapotec oral traditions. Mónica conducted research on language shift in Tehuantepec for her Bachelor thesis (García 2020). Both young women have been learning Isthmus Zapotec and have participated in a variety of different classes and workshops; Mónica was among the students in the $2^{\text {nd }}$ semester of the public course in 2013 when she first returned to the Isthmus to conduct research for her Bachelor's thesis and continued to participate in Zapotec classes in the Faculty of Languages and elsewhere. Focused and outgoing, they both aimed to conduct further graduate study (and are both doing so as I write) and to continue working on language issues in the Isthmus. Bania and Mónica were in their 20s when running the class; they fit in with the Bachelor students at the Faculty and spent time socializing with students. Based on their experiences in other Zapotec classes, and their areas of expertise, they developed a unique approach for their own class which aimed to be attractive to a wider range of students than the language classes had been. Their class on bilingual Isthmus literature aimed to challenge the coloniality of literature studies at Mexican universities, which typically hold up European authors and Mexican Spanish authors as those who produce "literature". They wanted to bring attention to the literary heritage of the Isthmus (see also chapter 6) and Isthmus Zapotec by having students read and discuss bilingual texts. They commented that the topic of literature was attractive to some students who were not interested in learning the language, but who might develop an interest through the avenue of poetry and stories. They saw this as complementary with the Zapotec-as-subject classes already offered in the Faculty, as Bania commented:

Bania El taller está ayudando mucho a entender este otra parte del zapoteco, que no solo es digamos saber aprenderlo, escribirlo, sino que tiene, este, más vertientes, más cosas a fondo. Creo que se esta complementando mucho.

The workshop [Literary Café] is really helping to understand that other part of Zapotec, that isn't just, let's say, knowing how to learn it, how to write it, but rather that has, um, more sides, more things deep down. I believe it is complementing [language classes] a lot.

(Interview January 2018)

Their class attracted a respectable amount of interest from students, including some who spoke Diidxazá and many who did not. Bania noted that the focus on literature and giving undergraduate students credit for the course were good strategies, because they also drew in students who were not previously interested in 
Indigenous language or literature, some of whom became more engaged through the class. Mónica brought a focus on 'rescate de zapoteco', reclamation of Zapotec, to the class, and when Bania moved to pursue a PhD in Linguistic Anthropology in autumn 2018, Mónica continued to teach the class for another year in collaboration with other members of the Faculty, and eventually with an expert language teacher from the nearby town of San Blas, Antonio Ortíz.

The successful representation of Indigenous languages as legitimate in the academic space involved explicit changes in the policies and practices of that space, in combination with a shift in perception among members of the Faculty community. Issues such as dialect diversity, lack of formal curricula, and low enrollment due to the prioritization of other languages continued to challenge the initiatives within the faculty, but clear positive results have been achieved. Aside from representing Indigenous languages on a par with European languages, another key strategy within the Tehuantepec Faculty of Languages has been attempts to support the education of potential future Indigenous language teachers. Considering that many people in the Isthmus would share Kiara Ríos Ríos's former view that Zapotec is "not for teaching" (as cited in the opening of this chapter), it is not surprising that there are few people who identify themselves as Zapotec teachers and little discussion of what characteristics a Zapotec teacher should possess. The next section discusses how teachers at the Tehuantepec Faculty have tried to help normalize this particular identity category.

\subsubsection{Creating Isthmus Zapotec teachers}

The lack of teachers, or lack of well-prepared teachers, is a common lament among minority language activists (Blair, Pelly, and Starr 2018). An expertise in language does not always translate into an expertise in teaching, depending on the interests and needs of the learners. In the case of the Faculty of Languages, the need to employ someone who would be willing to take on a few hours a week of teaching (far from a full-time job), make their own curriculum and exam plans and source all their own learning materials, was understandably challenging at times. Additionally, the students at the Faculty come from across the Isthmus, representing different Isthmus Zapotec dialects, and some with strong opinions about which dialects should be taught at the Faculty, as discussed in the previous section. The issue of recruiting and retaining qualified teachers was on-going throughout the first years of the program. Although the initial strategy was to hire a recognized language expert (even when they lacked a teaching background), the administrators soon saw the importance of investing in the pedagogical quality of the classes, and began to explore other options. 
The semester after the first class opened, I attended an event where students in the second year of the BA Bachelor program presented a variety of learning activities and resources as part of a class on Recursos Didácticos [Didactic Resources]. The students were asked to make learning materials for one of the main languages studied at the Faculty, and they had divided themselves into groups, focusing on English, Italian, and French, respectively. However, in this cohort for the first time there was a group who had asked - and been granted permission - to make materials in Diidxazá, which at that time was not considered a main language of study at the Faculty. I interviewed the teacher, Manuel David Ramírez Medina, about how the use of Zapotec in his class began. Manuel David is soft spoken and tall, and receives both respect and affection from students as I observed on many occasions. He is not originally from the Isthmus, but has lived there for many years, working in the areas of didactics and English teaching. Personally, and as a teacher, he takes a positive stance towards regional languages, expressing interest in learning Zapotec, although Spanish is the dominant everyday language in the part of the Isthmus where he lives and works.

HDK $\quad Y$, ¿cómo, cómo pasó que--- pues yo sé que en tu clase de, de este semestre pasado los alumnos se pusieron a elaborar materiales didácticos en zapoteco. ¿Podrías contarme cómo surgió este proyecto?

Manuel David La materia en sí se llama recursos didácticos, estrategias y recursos didácticos y me piden [enseñar] la elaboración de material didáctico. Se supone está orientado a inglés, francés o italiano. Entonces, eh, Carlos, Carlos Gómez levanta la mano y me dice: ¿podríamos hacerlo en zapoteco? y a mí se me ocurre: sí, adelante. Háganlo en zapoteco. No fue algo planeado, fue así de, de improviso. Ya después comentando con [los coordinadores] Omelino y con Ximena decían: es que ahorita ya también estamos tratando de hacer todo el proyecto para [que] el zapoteco tenga el mismo peso que los demás idiomas políticamente fuertes. Entonces fue que ya les empecé a abrir más la puerta en cuanto a elaboración de todo el tipo de material en zapoteco que ellos quisieran . . . en parte para este, que ellos se sientan cómodos con el material que están trabajando, porque para ellos es más cómodo trabajar en zapoteco que trabajar en inglés. Entonces esa fue principalmente la, la causa, la petición de un alumno.

HDK ¿Ah, sí? Eh, en los años que llevas trabajando aquí, ¿ningún alumno antes había mostrado un interés?

Manuel David No. No en la elaboración de material. Sí habíamos tenido algunos que hablan zapoteco, y este--- pero ni uno de ellos se había interesado en enseñarlo o en elaborar algo en zapoteco. Es la primera vez que me encuentro con eso. 
HDK

And how, how did it happen that--- well I know that in your class in, in um this past semester the students started to make didactic materials in Zapotec. Could you tell me how this project emerged?

Manuel David The subject itself is called didactic resources, strategies and didactic resources, and I'm asked [to teach] the creation of didactic material. Supposedly it's oriented to English, French or Italian. So eh, Carlos, Carlos Gómez raises his hand and says to me: could we do it in Zapotec? And it occurs to me: Yes, go ahead. Do it in Zapotec. It wasn't something planned, it was like that, improvised. Then afterwards talking with [the coordinators] Omelino and with Ximena they said: actually now also we're trying to make a whole project so [that] Zapotec would have the same weight as the other politically strong languages. So that was when I started to open the door to them in terms of creation of all of the kinds of materal in Zapotec that they wanted . . . In part so um, that they feel comfortable with the material that they're working on, because for them it's more comfortable to work in Zapotec than to work in English. So that was primarily the, the cause, the request of a student.

HDK

Oh yes? Ah, in the years that you have been working here, no student before had shown an interest?

Manuel David No. Not in the creation of didactic material. Yes we've had some students who speak Zapotec, and um--- but not one of them had been interested in teaching it or in making something in Zapotec. It's the first time that I find that.

(Interview January 2014)

As a teacher, Manuel David wanted his students to "feel comfortable with the material that they're working on", so as to have a better chance of succeeding in their studies. He acknowledged that having students who speak Indigenous languages was not new, but the interest to include them in certain academic activities of the Faculty alongside European languages was novel. His response to his students' interest, alongside the existing initiative in the Faculty to provide Zapotec classes, helped to raise the visibility and acceptance towards Indigenous languages in the Faculty. Alongside the coordinators, he acted as an arbiter of language policy change through supporting the students' interests.

The coordinators of the public courses, the BA Bachelor program, and motivated teachers such as Manuel David, talked together about how to make the most of the interests and abilities of the Bachelor students as a possible resource for teaching Diixdazá and other languages. The Bachelor program required the students to do dozens of hours of teaching practice, and the coordinators agreed that one way to help make the Indigenous language courses sustainable would be encouraging upper-level Bachelor students to take on teaching and developing curricula for Indigenous language classes. They could then receive credit for these 
efforts to help meet the requirements of their program and help them towards graduation at the same time.

Four Bachelor students representing 2 different dialects took up the invitation to teach the class as a group in winter 2014. It was their first time in front of a class. None of them had had Zapotec as part of their schooling, rather they used it to varying degrees in their homes and communities. Although they were clearly nervous when they began teaching, over time they acquired both more confidence and more expertise. They applied the pedagogical techniques they had learned through the Bachelor program in order to make the class interactive, with students asked to create their own learning materials, songs, and dialogues. Figure 15 shows students and teachers sharing an end-of-semester potluck meal, after having played some of the games that the students themselves created, and singing songs accompanied by one of the students on his guitar. The student-teachers were pleased with the progress of their students and with their interest in Diidxazá. They worked with a senior language expert to develop some of their lesson plans and to check words that they were not certain of. They also aimed to teach both the variety of Juchitán and the variety of San Blas/ Tehuantepec, benefiting from speakers of these 2 varieties in the teaching team. Although the studentteachers brought in a variety of games, songs and interactive exercises, they also maintained a strong focus on writing, often presenting material on the board for the students to copy.

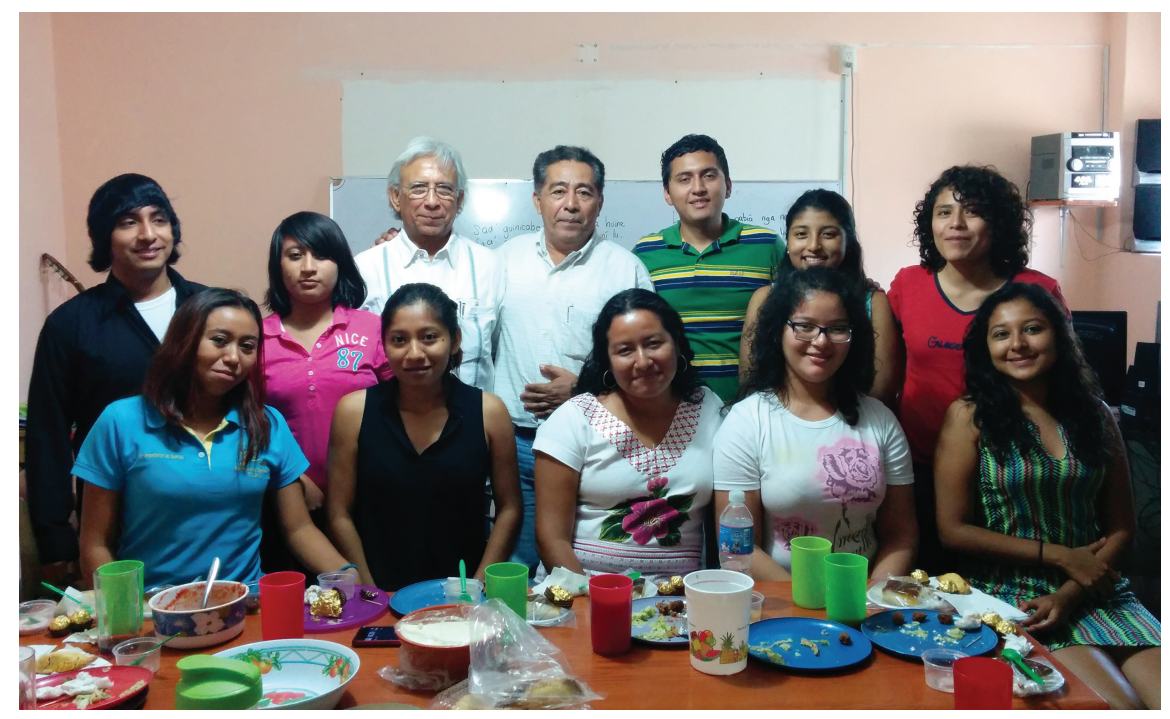

Figure 15: Students and teachers sharing a meal at the end of the semester (photo July 2014). 
The team of teachers had explicitly decided to include both varieties in the class, however this was very challenging in practice. As one of the teachers of the smaller, San Blas variety commented when asked about some of the things that were difficult as a new teacher:

\begin{abstract}
Student teacher A veces era dificil enseñar a las personas--- es que se va pronunciar así y se escribe así pero en el momento que . . . .lo pronunciaba ese [un maestro de Juchitán], pues si sonaba bien, con la escritura. Pero en la forma en que yo pronunciaba como que no, no iba. [. . .] Era como algo difícil, a mí, a mí me sigue costando trabajo, trabajar con la escritura que tiene los de Juchitán. Que ellos son los que ya lo establecieron ¿no? Es como que muy difícil.

Sometimes it was difficult to teach people- you pronounce it like this and it's written like this, but at the moment when ... . [the Juchitán teacher] pronounces it, well yes it sounded good, with the writing. But the way that I pronounced, like it didn't . . . it didn't go. [. . .] It was like something difficult for me, for me it still requires a lot of work, to work with the writing that the people from Juchitán have. That they're the ones that already established it, right? It's like really difficult.
\end{abstract}

(Interview July 2014)

The prominence of the Juchitán variety in the existing written materials was a challenge as this teacher worked to make their variety of Zapotec understood and legitimate within the class. The writing-focused pedagogy in the class made this additionally difficult for the team of teachers, who struggled with their desire to write "correctly" and to include different varieties, when they had previously used Diidxazá orally and had been schooled only in Spanish through their entire educational trajectories. The student-teachers were given feedback by Ximena and myself, and made significant progress in expanding their pedagogical approaches and becoming comfortable as teachers, although they continued to be challenged by the task of meeting the expectations of a varied student group and making space for multiple dialects in the classroom.

In autumn of 2014 I organized a trip for four of the junior teachers to visit two Indigenous language teachers in Oaxaca City (whose classes I had previously observed and admired), as well as a linguistic library and the Centro de Estudios y Desarrollo de Lenguas Indígenas de Oaxaca [Center for the Study and Development of Indigenous Languages of Oaxaca, CEDELIO], strategizing that personal observation, exchange, and a bit of big city glamour might be more helpful and motivating in their development as Zapotec teachers than written and oral feedback from myself and Ximena had been. When visiting the Research Library Juan de Córdova, the librarian had kindly pulled out books relevant to the Isthmus for them to look at, which they dove into eagerly. They commented on how surprised they were to see so many books in Diidxazá, far 
more than they had ever seen in the Isthmus, and they appeared genuinely excited, taking many photos of pages with their phones. The librarian told them they would be welcome to visit the library anytime. One young man, while paging through a copy of Mexico South by Miguel Covarrubias suddenly commented that this was the first book he had ever had a personal desire to read. The visits to other Zapotec classes and the CEDELIO seemed largely successful, as the junior teachers enthusiastically met with other Indigenous language professionals during the trip, and afterwards expressed their inspiration and desire to make their own professional Isthmus Zapotec syllabus.

This, and other positive reactions, made me feel that the strategy of improving the UABJO Zapotec program through fostering competent and motivated teachers (as opposed to writing a curriculum for them) was at least partially effective. The strategy to connect young teachers with potential colleagues and role models seemed helpful in supporting their professional development. Observing and accompanying this program over several years made it clear to me that competent teachers are necessary for a structural change to be sustained and accepted by all members of the institution. In educational efforts for minority language equality, teachers are an invaluable resource. Minoritized language teachers often have extra challenges, including dealing with the language-internal diversity that is the norm in non-standardized, Indigenous language communities, being creative in making or adapting materials, and facilitating an engaging learning environment where students can build communicative competence and confidence, while managing the insecurity and hurt that may have been part of being a minoritzed language speaker or learner.

Although a majority of students at the Faculty of Languages continued to choose to focus on European languages, and only a small group of Bachelor students have participated as Zapotec student-teachers, this is an important change in comparison with the European language-only norm that was in place in the Faculty in the past. Ximena argued that these changes were not token gestures in favor of Indigenous languages, but carried an important symbolic and practical weight:

Ximena No importa si lo chicos estudian 4 años de inglés, 2 de francés y 1 de italiano, y que no llevan zapoteco como materia obligatoria en la carrera, no; importa el hecho de que ellos saben hoy por hoy que aunque así sean sus estudios, ellos pueden dedicarse o hacer su proyecto de titulación o su servicio social exclusivamente en zapoteco se así lo desean. Eso es algo que no sucediera con ninguna circunstancia [antes].

It doesn't matter if the students study 4 years of English, 2 of French and 1 of Italian, and that they don't take Zapotec as a mandatory subject in the program, right; it matters that they know right now that even if their studies are like that, 
they can dedicate or do their graduation project or the social service entirely in Zapotec if that is what they want. That is something that didn't happen under any circumstance [before].

(Interview July 2014)

For students like Kiara Ríos Ríos, quoted in the opening of the chapter, simply being acknowledged as Indigenous language speakers and coming to see this as a positive thing within an educational institution was a significant change. The ability to gain academic credit for work related to Zapotec was an additional important strategy which the Faculty administrators and teachers used in order to change the ideological and practical hierarchy of languages within the Faculty. Although European languages still maintained a high visibility (and were of genuine interest for many Istmeño students, keen to learn about other cultures and languages) local languages were no longer made invisible or viewed as irrelevant within higher education.

\subsection{Summary: Characteristics of higher education activism}

Language activism within higher education has significant potential to dismantle the coloniality and Eurocentrism of the traditional curriculum, and to support new legitimate, high-status identities for Indigenous language speakers as experts and teachers. Additionally, changing the bureaucracy to create new spaces or structures may be more achievable within a higher education institution than within primary and secondary schooling (although it is never straightforward), as discussed in chapter 4. A less-centralized curriculum and relatively fewer layers of bureaucracy can make it easier for teachers and arbiters in higher education to enact changes in what is taught or how teaching occurs. In all formal education contexts, negotiating standard language ideologies in order to teach a language with several accepted variants remains a challenge. The efforts of the coordinators and teachers at the UABJO Faculty of Languages made meaningful changes through normalizing the presence of Indigenous language classes, getting more people involved in teaching them, and providing professional development to Indigenous language teachers. The key language activism strategies in this context are schematized in Table 4. Through representing Indigenous languages and younger speakers as legitimate within the higher education institution, the UABJO has made an impact on the perceptions of future language teachers, whether they speak an Indigenous language or not. The creation of spaces for learning and/ or teaching Indigenous languages within the structure of the university, recognized by university credit, helped to establish a more positive representation, as well as to develop actual language and teaching competence. 
Indigenous language teachers have numerous challenges, and connecting them with role models as well as with resources went a small way towards meeting some of these challenges.

Table 4: Key language activism strategies in higher education in the Isthmus.

\begin{tabular}{|c|c|c|}
\hline Actions $\rightarrow$ & Goals $\rightarrow$ & Examples \\
\hline - Representing & $\begin{array}{l}\text { - Communication practices } \\
\text { - People/ Identities }\end{array}$ & 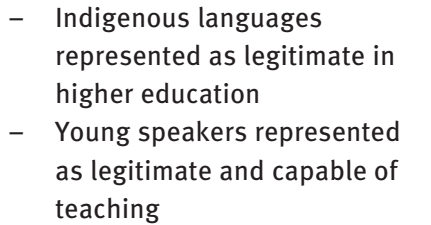 \\
\hline - Creating & - Spaces/ Structures & $\begin{array}{l}\text { - Indigenous language classes } \\
\text { for credit; Teaching practicum } \\
\text { in Indigenous language as part } \\
\text { of existing BA structure }\end{array}$ \\
\hline - Creating & - People/Identities & $\begin{array}{l}\text { - Institutionally certified } \\
\text { Indigenous language } \\
\text { teachers }\end{array}$ \\
\hline - Connecting & $\begin{array}{l}\text { - People/ Identities } \\
\text { - Resources }\end{array}$ & $\begin{array}{l}\text { - Young teachers introduced to } \\
\text { experienced teachers } \\
\text { - Young teachers introduced to } \\
\text { books and materials }\end{array}$ \\
\hline
\end{tabular}

In relation to the characteristics of these strategies, they were carried out primarily at the local level of the Faculty of Languages with little wider visibility, although trends and discourses from national and international sources were also drawn upon discursively in promoting Indigenous language classes. The structural change of including Indigenous languages for credit was also a slow, long-term effort, that required on-going trouble-shooting and adjusting over time. Although the teachers working in this context aimed for a somewhat syncretic approach, by including multiple dialects, the standard language ideology that dominates in education settings exerted a purist influence. As with the activism initiatives in primary and secondary school, the ability for motivated individuals to propose some form of action which was then accepted and supported by the institution was key in this setting. The institutional setting did not allow for fully open participation, but it was flexible enough to allow for new initiatives to emerge and to be integrated into the existing structures. 
While there are indications that the changes in perspective and in structures will be sustained at the Tehuantepec Faculty of Languages, there is always a risk that they will not. Returning to the professional-development trip for four studentteachers from Tehuantepec in 2014, described in the section above, it is important to note that the semester after this trip three of the four student-teachers opted to stop teaching Zapotec in order to devote more time to other activities. This does not negate the learning and positive exchanges that occurred, but it does make clear that contextual pressures still go against these language activism efforts. As undergraduate students look to their future employment opportunities, and the score they are required to achieve on the TOEFL test ${ }^{28}$ in order to graduate, they may choose to set their work with Zapotec aside no matter how enthusiastic they are about it. Of the numerous students who became involved with Zapotec teaching while studying in the UABJO, many have gone on to work as English teachers or with English in the tourism industry. As a member of the UABJO community of practice they came to value their Zapotec capacities, but when they left the university and entered the job market many of them have oriented towards English as the most immediate source of employment in a difficult economic landscape. The complex links between Indigenous language use, educational success, and professional success put a limitation on the changes that can be achieved within a school, whether primary, secondary, or higher education (Hornberger 2008). Language activism within higher education can extend beyond the walls of the institution, however, as the confident young multilingual professionals who are fostered there become part of the wider language ecology for decades to come.

The coordinators in Tehuantepec have continued to seek and support more new teachers from among the Bachelor students and alumni, viewing this as a crucial area which can make or break the success of the Indigenous language classes in the Faculty. Generating and maintaining enrollment has also been a challenge. In the Oaxaca City campus, Kiara Ríos Ríos, the former Bachelor student quoted in the opening of the chapter, has established a 4-level curriculum of Isthmus Zapotec classes with a healthy enrollment, and other Indigenous languages have been offered on a less-regular basis. Although there have also been challenges in the Oaxaca City campus, the high popularity and effectiveness of Kiara as a teacher is one of the factors which has kept the program running, as well as the strong commitment of the administration (De Korne, López Gopar, and Ríos Ríos 2019). Despite efforts from the coordinators in Tehuantepec, a similar degree of success has been elusive there, where Indigenous

28 A standardized test of English as a foreign language which is used extensively in higher education around the world. 
languages are in some ways less appealing to students (and student-teachers) because they are so much a part of the everyday. An everyday, which, as discussed in section 5.1, involves denigration of Indigenous language speakers and discouragement of young speakers in particular. This symbolic violence or trauma does not evaporate as soon as young speakers enter a more accepting environment. Even though Bachelor students have become accustomed to the fact that Indigenous languages are valued and part of the curriculum within the Faculty, they continue to face prejudice and ideologies which devalue these languages on their way to and from the Faculty each day.

Language activism that aims to produce a new structure, such as a recognized class or an education system that supports Indigenous language teachers, is slower than the production of some materials or a one-off event, but it has important potential to create more long-term changes. This has also been evidenced in other higher education contexts where groundbreaking choices were made to change educational norms. Just a few examples include the Indigenous teacher education program at PROEIB Andes in Bolivia (Hornberger 2009) and other 'Intercultural Bilingual Education' initiatives in Latin America (Maurial and Suxo 2011), the establishment of the Myaamia Center at Miami University in the United States (Mosley-Howard et al. 2016), and the Indigenous Language Revitalization programs at the University of Victoria, Canada (Czaykowska-Higgins et al. 2017), among others. In order to sustain this process, connections among colleagues across institutional spaces can be helpful in providing role models as well as solidarity and understanding for the challenges that all innovators are likely to face. Here again the importance of arbiters (Johnson 2012), or social actors with a specially-important local position in the chain of language politics, is exemplified in the choices made by key administrators and teachers, and the ways they responded to students' interests. The responsive attitude of the teachers and administrators towards the proposals of students and motivated teachers, such as the Literary Café or the students making Diidxazá materials as a final project, was an important open door in the process of change. If the administrators supported Indigenous languages in a tokenistic way only, these kind of proposals would likely not appear, nor receive tangible support. Ximena recounted that the Tehuantepec Faculty had always had events focused on local culture, and that Zapotec had sometimes been spoken as part of those events, but never outside of them:

Ximena Pero lo hacían [hablaban zapoteco] solo para esos eventos. No recuerdo que mis compañeros, los que hablaban zapoteco dentro del salón, se comunicaran en zapoteco como ahora escucho muchos de los alumnos de la nueva licenciatura que van caminando por los pasillos de la facultad y entre ellos hablan zapoteco, no? No creo que eso succediera tanto en mi época. 
But they did it [spoke Zapotec] only for those events. I don't remember that my classmates, those that spoke Zapotec in the [cohort], would communicate with each other in Zapotec like now I hear many of the students in the new Bachelor program that go walking through the corridors of the Faculty and between themselves they speak Zapotec, right? I don't believe that that would have happened much in my era [as a student].

(Interview July 2014)

Although Ximena and other higher education language activists have even larger changes as long-term goals - such as establishing Indigenous languages as a curricular requirement, or graduating more Indigenous language teachers creating a space where young professionals feel confident to use all their languages and where they and their languages are viewed with respect is a laudable achievement. 